\title{
A Critical Praxis in the Information Literacy Education Classroom Using the ACRL Framework for Information Literacy for Higher Education
}

\author{
Shehaamah Mohamed ${ }^{(\varpi)}$ \\ Information Literacy, University of the Western Cape, Cape Town, South Africa \\ shmohamed@uwc.ac.za
}

\begin{abstract}
The University of the Western Cape Library uses the ACRL Framework for Information Literacy for Higher Education to introduce an alternative, nuanced approach to information literacy training by transforming librarians' teaching praxis. The Framework presents a new perspective on teaching and learning and is built around six frames, each consisting of a threshold concept which is central to information literacy. To this end, the Library coordinated the Information Literacy Programme for the University's Library and Information Science Department. By using a qualitative approach, this case study describes the integration of the Framework in the Information Literacy Education module to teach prospective librarians to internalise the core concepts of the Framework. The paper discusses how the Framework was operationalised to enhance students' critical thinking through the application of formative and summative assessments and a number of student artifacts.
\end{abstract}

Keywords: ACRL framework for information literacy for higher education Critical praxis $\cdot$ Critical thinking $\cdot$ Constructivism $\cdot$ Authentic assessment $\cdot$ Information literacy education

\section{Introduction and Background to the Study}

Prior to 2016 when the official approval of the ACRL Framework for Information literacy for Higher Education [1] (the Framework) occurred, many academic libraries in South Africa had subscribed to the ACRL Information Literacy Competency Standards for Higher Education [2] (the Standards). According to the latter, an information literate person is one who is able to "recognise when information is needed and [who has] the ability to locate, evaluate and use effectively the needed information" [2, p. 2]. Librarians thus provided library instruction which teaches students to navigate the set of library tools and resources. However, to be competent and capable in the $21^{\text {st }}$ Century, learners require a completely new set of capabilities.

S. Mohamed-Senior Librarian: Information Literacy 
The discourse of practitioners in the field of information literacy has changed fundamentally in the past few years. According to Hepworth [3], the contention is that the centre of this field has shifted from a predominant concern with technique (navigating databases and locating information) towards critical engagement with information. Unfortunately, library practices which were largely based on the Standards, limited learners' capabilities to become flexible and to take the initiative when necessary when working with various modes of information.

Furthermore, Elmborg [4] claims that the previous ARCL definition of information literacy lacks an element of critical thinking. He argues that librarians should redefine their roles to become educators of critical theory and "coach intellectual growth and critical development" [4, p. 198]. Moreover, there is a consensus amongst LIS specialists that by becoming information literate "one moves beyond knowing how to access information to becoming a critical citizen" [3, p. 31] who questions the validity of all texts and utterances.

Due to its inadequacy in addressing these fundamental elements, the Standards, advocating a rigid set of outcomes and performance indicators, were consequently rescinded and replaced with the Framework. The Framework, on the other hand, regards information literacy as a "set of integrated abilities encompassing the reflective discovery of information, the understanding of how information is produced and valued, and the use of information in creating new knowledge and participating ethically in communities of learning" [1].

To this end, the purpose of this study is to examine how the Framework's threshold concepts may be operationalised for training postgraduate students to internalise them. Hence, this paper will discuss how a postgraduate course was restructured to embed the threshold concepts of the Framework in learning activities and will examine a range of student artifacts that were designed to enhance critical literacies. Fundamentally, the aim of the study is to enhance students' critical thinking skills through the application of the Framework. Apart from Fullard [5] who explored the relevance of the Frames for literacies for higher education, there has been little discussion about its application in information literacy education programmes within a South African higher education context.

\section{Theoretical Background}

\subsection{The Need for Critical Information Literacy}

The banking model concept which was first coined by Freire [6] in 1970 describes the education system as a capitalist ideology which deprives learners from exercising their own critical thinking proficiencies. Freire [6] proposes that students should no longer be passive consumers of information but should rather be encouraged to actively shape their own lives through critical consciousness. This implies that students should be taught to "identify and engage significant problems in the world" [4, p. 193] instead of being fed information by "authoritative" figures. Students should thereby exhibit dispositions of being critically and relevantly literate. 
Critical information literacy includes the ability to adopt critical perspectives toward text, utterances and other modes of information. Bauder and Rod [7] recommend that librarians should teach students to engage more meaningfully with information. For instance, in addition to showing students how to locate information sources, they should demonstrate ways in which its authority may have been constructed by a scholarly community or how the source fits into a scholarly conversation around the topic [7, p. 262]. This ability to interrogate various modes of information in this manner is indicative of a critical information literacy skill.

Moreover, the Framework reinforces the notions of critical literacy and critical consciousness through some of its knowledge practices and dispositions. When questioning authority for example, students should "understand that many disciplines have acknowledged authorities ... and that some scholars would challenge the authority of those sources" [1, p. 4]. By the same token, they should also be taught to question how "some individuals may be underrepresented or systematically marginalised within the systems that produce and disseminate information" [1, p. 6]. Hence, in more ways than one, the Framework may be seen as a model which demystifies Freire's [6] concept of critical consciousness and abandons the banking model of education.

It may therefore be inferred that developing integral questions is a skill which is central to critical information literacy and equally, that librarians should design appropriate assessments and learning activities that would nurture this skill.

\subsection{Critical Information Literacy Through Formative and Summative Assessments}

Information literacy has become increasingly important in higher education institutions over recent years Anderson [8] and Hepworth [3]. Subsequently, academic librarians have experienced increased pressure to assess the information literate capabilities and higher order thinking skills of learners, Whitlock and Nanavati [9]. Moreover, our rapidly changing information landscape has transformed the ways in which assessments are designed, as most of the types of assessments that were being used over the years have been aimed at supporting the Standards [7].

According to Halbach [10] and Whitlock and Nanavati [9] it is important to differentiate between the categories of assessments: the librarian could evaluate students during the course of the lesson and while the learning activity is taking place (formative), or assess them at the end of the activity (summative). Common forms of assessment are multiple choice tests (objective), testing search strategies or techniques in class (performative) and assessing what students can do in a real-world context (authentic). An examination of various forms of authentic assessment is of significance to this study as it includes presentations, group discussions, reflective writing and peer assessment.

Recent studies show how librarians have designed different assessments that are aligned with the Framework. In their application of the Frame, Research as Inquiry, librarians Couture and Ladenson [11] used discussion groups to help students analyse their individually assigned research topics. It was found that participatory environments enhance students' critical literacy and ability to question. Citing Brookfield and Preskill [12], Anderson [8] confirms the value of allowing group discussions in IL training as it 
facilitates collaborative learning and helps learners to analyse their own assumptions. Moreover, the advantages of group discussion are associated with the Framework which envisions that students should be able to "contribute to scholarly conversations at an appropriate level" [1, p. 8].

In his article which investigates how social media facilitates teaching and learning, Dominic Chawinga [13] finds that the integration of blogs and Twitter into teaching methods enhances the effectiveness of the teaching praxis. More significantly, he claims that the extended time that the lecturer and learner spent posting comments and feedback means that teaching and learning was taking place beyond the classroom $[13$, p. 16]. Anderson [8] reinforces this notion by affirming that blogs function well as formative assessments and that they may be seen as user-generated instructional tools [8, p. 8]. Furthermore, sharing critical commentary on blogs develops the understanding of Scholarship as Conversation as learners should be able to "critically evaluate contributions made by others in participatory information environments" $[1$, p. 8$]$.

Online discussion boards, for instance, are commonly used in information literacy training as they allow the learner to reflect on content by way of "individualistic critical thought" [8, p. 6]. Halbach [10] concurs with Anderson [8] by stating that students' reflection often describe their own perception of the course and the issues that they find challenging. The skill of critical reflection is congruent with the Framework's concept of Authority is Constructed and Contextual where students should be able to "acknowledge that they are developing their own authoritative voices in a particular area..." [1, p. 4] through questioning and seeking solutions.

To this end, this study aims to examine the following research questions: (1) How does the Information Literacy Education (ILE) module reflect the ACRL Framework? and (2) How do Library and Information Science students develop critical thinking and agency through application of the ACRL Framework in the ILE module?

\section{Methodology}

\subsection{Research Design and Method}

This case study explores the ILE module in depth and "within its real-world context" Yin [14, p. 16] in which the researcher aims to provide an in-depth description and analysis of the case. The study therefore examines how the Framework emerged in the module through the pedagogical approach adopted by the researcher, and will analyse the various assessments that students completed.

\subsection{Case Study Environment}

The case selected for this study is the ILE module (LBS707) that is offered biennially in the Postgraduate Diploma in Library and Information Science (PGDipLIS) Programme at the University of the Western Cape. 
The ILE module required a complete restructuring for it to reflect a modified module descriptor with revised learning outcomes and assessments that complement the ACRL Framework. This guided the researcher to adopt a single case study design as this study focuses on the analysis of two academic years within the context of a single case.

The researcher selected two cohorts of students for the years 2015 and 2017 as study participants for the ILE module (LBS707).

The cohorts exemplify broad heterogeneous groups with the following characteristics:

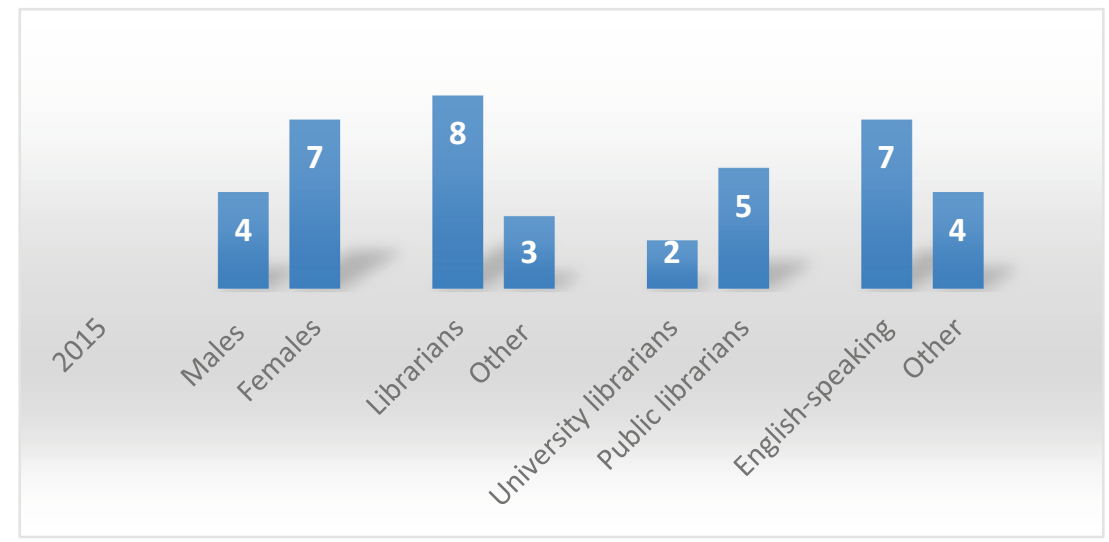

Fig. 1. Study sample for 2015 (LBS707)

The study participants for 2015 consisted of 11 students, 4 of whom were male and 7 who were female. Sixty three percent $(n=8)$ are employed within the Library Science fraternity with 2 students who are faculty librarians at the University of the Western Cape (UWC) library and 6 students who are public librarians. The remaining participants are not affiliated with the Library Science discipline and have chosen to

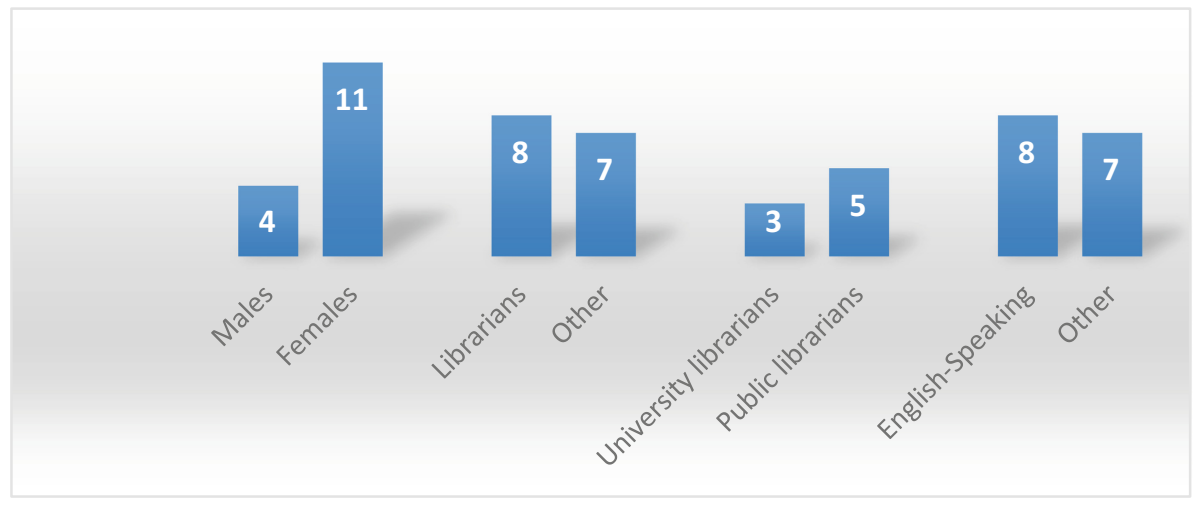

Fig. 2. Study sample for 2017 (LBS707) 
obtain a postgraduate diploma in Library and Information Science as an additional qualification for career development. The majority of the LBS707 class were Englishspeaking (Fig. 2).

The study participants for 2017 consisted of 15 students, 4 of whom were male and 11 who were female. Fifty three percent $(n=8)$ are employed as librarians with only 3 students who are faculty librarians at a university library and 5 students who are public librarians. The remaining 47 percent $(n=7)$ participants are employed as social workers $(n=2)$, teachers $(n=4)$ and insurance consultants $(n=1)$ and have indicated that the PGDipLIS will assist them with career advancement. The majority of the LBS707 class were English-speaking.

\subsection{Data Collection Techniques and Analysis}

Data collection techniques such as observation, interviews and document analysis were used:

Observation. This particular method was used to sample activities in class on a predetermined basis using a prearranged instrument into whose categories the researcher recorded class presentations Gorman and Clayton [15, p. 104]. The researcher used structured participant observation where rubrics were used as data collection instruments. The researcher's perspective of the class presentations were based on the observer-as-participant observation technique where she interacted to some degree with her research subjects during group presentations and poster designs. This was aimed at clarifying certain observations pertaining to the conduct of students as well as their reaction to certain issues.

Interviews. Structured interviews were used to gather data from selected participants for the 2015 and 2017 academic years. Predetermined questions and answer categories were prepared gathering data from $42 \%(n=11)$ of the study subjects. The researcher read out written questions to the interviewees and coded the answers into categories.

The Use of Documentation. The researcher collected data from both physical hard copy documentation as well as online texts. The student weekly reflections, class activities, blog posts including lesson plans, and posters including student feedback were the instruments used to glean a description of the delivered course from the students' perspective. Secondary sources such as journal articles and internet sources were used to compile a theoretical background for this case study. This information was collected and integrated with the data obtained from the study participants in an attempt to clarify the themes and research objectives.

The study adopts a thematic analytical approach and uses a wide range of data sources. This includes notes based on observation, interview transcripts, information written by participants (e.g., reflections), tests, lesson plans, posters, and presentation transcripts (PowerPoint Slides). The data was analysed and codified in the form of specific themes for each research objective. Some memos depicting the researcher's interpretation were added to data sets. 
The researcher obtained written permission from all students who were registered for and who attended the ILE classes for the years 2015 and 2017. The students were guaranteed anonymity as their identities are not attached to the data sets and to the feedback that was obtained through interviews.

\subsection{Reflective Approach}

According to Ferreira [16], "reflecting" on one's practice means "retrieving past activities and situations to open mental space". The lecturer thus spends time after the practice to decipher information in a more analytical manner. Through critical reflection and scrutiny, the researcher is able to provide an analysis of the pedagogy and assessments assigned to her students. Moreover, by using a critical reflective approach, the researcher aims to develop a new understanding of her experiences which might aid her in reformulating her teaching methods. She reflects on her own experiences and thus tries to "unearth different assumptions and interpretations" Fook [17, p. 56].

\section{Findings}

\subsection{How Is the ACRL Framework Reflected in the ILE Module?}

This study was the first step in transitioning away from the Standards-based information literacy instruction method for the postgraduate diploma course. The new module was essentially guided by the six threshold concepts namely; Scholarship as a Conversation, Research as Inquiry, Authority as Constructed and Contextual, Information Creation as a Process, Searching as Strategic Exploration, and Information has Value.

Relevant learning outcomes were crafted for the course where students are expected to:

(a) explain the concept of information literacy and relate it to other literacies and learning theories

(b) understand and apply the core ideas of the ACRL Framework of information literacy in library teaching practices

(c) design and run Information literacy programmes for libraries of all kinds using the ACRL Framework

(d) present effective IL workshops on the Framework in which learning outcomes are identified and assessed

(e) design appropriate lesson plans to enhance understanding of the Framework.

The curriculum followed a continuous assessment plan and incorporated assessments which reflected the Framework. Weekly group discussions embrace the notion that scholarship is a conversation. Designing posters provides the opportunity to understand that information creation is a process. Informal online peer review means that students are able to critically evaluate the contribution of others, and using images and text located on the internet helps them to develop the ethics of sharing information. All class activities were aimed at enhancing an understanding of the Framework's concepts. 


\subsection{How Can the ACRL Framework Enhance Critical Thinking?}

\section{Weekly Group Activities and Tests}

Benefits and Limitations of Class Activities: It is proffered that group exercises enable greater collaboration on various interpretations of the Framework and force students to engage with one another Haigh [18]. Such interaction also offers them the opportunity to critically reflect on the knowledge practices and dispositions of the Frames through pertinent examples and activities: "The discussions helped me to understand the content better...we would discuss different views [of the Frames] and include it in our results" (Student 2: 2017).

It was also emphasised that weekly tests were easy and beneficial as it assessed work which was "fresh in one's memory" and "if you listened and participated in class the test would be very easy to pass" (Student 3:2017).

However, one of the interviewees (Student 1:2015) suggested that the group activities should rather have been completed at home where the student would be able to focus in a more comfortable setting without feeling pressured to complete the exercise or test immediately after the lesson: "A take home test or activity would have been more doable as it allows the student time to revise the work" (Student 1: 2015).

Through observation, the researcher found that some students performed well with group activities while some of these activities might have been challenging for certain individuals due to their lack of computer literacy skills or due to the fact that some of them may be novice researchers. Upon reflection, the researcher acknowledges that additional assistance in this regard may have been required and intends to incorporate these factors in future planning of her assessments. An example of a class activity is found in Table 1 where students were instructed to match the learning outcomes with appropriate activities for the Frame "Scholarship as a Conversation".

Table 1. Activity for the Frame "Scholarship as a Conversation". Match the learning outcomes with appropriate activities

\begin{tabular}{l|l}
\hline Learning outcomes & Activities \\
\hline $\begin{array}{l}\text { 1. Recognize that a given scholarly work } \\
\text { may not represent the only_or even the } \\
\text { majority_-perspective on the issue at hand }\end{array}$ & $\begin{array}{l}\text { a. Select a topic on which students have } \\
\text { some knowledge or experience. Identify a } \\
\text { venue (blog, discussion forum, other social } \\
\text { media site) in which a scholarly conversation } \\
\text { is taking place }\end{array}$ \\
\hline $\begin{array}{l}\text { 2. Critically evaluate contributions made by } \\
\text { others in participatory information } \\
\text { environments }\end{array}$ & $\begin{array}{l}\text { b. Find } 2 \text { articles on the topic, one of which } \\
\text { is a rebuttal to the other }\end{array}$ \\
$\begin{array}{l}\text { 3. Students will recognise information } \\
\text { sources as conversational and dialogic in } \\
\text { nature }\end{array}$ & $\begin{array}{l}\text { c. Create a timeline to track the evolving } \\
\text { threads of a continuing scholarly } \\
\text { conversation }\end{array}$ \\
\hline $\begin{array}{l}\text { 4. Recognise that they are not just consumers } \\
\text { of knowledge but also producers thereof }\end{array}$ & $\begin{array}{l}\text { d. Ask students to discuss and critically } \\
\text { respond to this blog post }\end{array}$ \\
$\begin{array}{l}\text { 5. Understand that conversations around } \\
\text { topics include both scholarly and non- } \\
\text { scholarly pieces of information }\end{array}$ & $\begin{array}{l}\text { e. Discuss your findings on a Facebook page } \\
\text { which explores your topic }\end{array}$ \\
\hline
\end{tabular}




\section{Online Blog Activities}

(i) Lesson plans: Preparing future librarians to teach the Framework

Using a rubric to guide their thinking, students were asked to create weekly lesson plans for each Frame and post these as blog entries. The lesson plans had to comprise learning outcomes, learning activities and an explanation of how these activities would enhance understanding of the threshold concepts, knowledge practices and dispositions. Approximately half of the 2015 cohort $(n=5)$ and 80 percent $(n=12)$ of the 2017 cohort produced lesson plans that may foster critical thinking and which portray a fair understanding of some of the knowledge practices of each frame.

\section{The Benefits of Informal Peer Review}

As illustrated in Fig 3, the blogger platform also served as a forum for commentary and discussion and the researcher encouraged peers to offer constructive feedback to each other's work. This shows that they possess knowledge and understanding of the Frames as they are able to critique the views of others: "I wasn't sure how to put [the lesson plan] together... reading and commenting on other lesson plans online and receiving comments from others really helped me to understand" (Student 2: Cohort 2017) (Fig. 3).

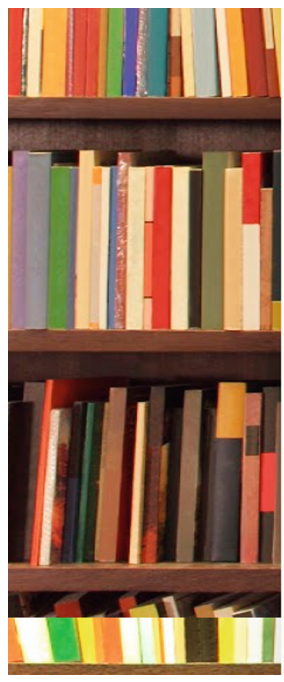

\section{Posted by charlene petersen at 06:59 MB}

4 comments:

Fill Nizam Bray 9 August 2015 at 12:13

Dear Charlene,

From your post one can tell that you have grasped the Frame: Scholarship as a conversation quite well. I also understand it in the way you have explained it.

Just on your assignment, for me your first activity links more to the disposition that states "learners... seek out conversations taking place in their research area". The disposition you make mention of I understand it a bit differently. I feel its not a particular issue that judgement is withheld from by the researcher, but rather a specific piece of "writing" or scholarship as mentioned in the ACRL Framework. Reply

charlene petersen 9 August 2015 at $13: 49$

Thank you for you observation Nizam. I think I was also not $100 \%$ sure that is why I also mentioned the Knowledge Practice. It will take a bit of time for me to fully comprehend all of the Framdwork

Reply

Fig. 3. Critical peer feedback (2015 cohort)

The lecturer's comments on the blog entries allowed opportunity for reflection and modification of the way in which the frames may be taught. As one of the students states "As a social worker, I was never in the position to teach so I was not sure whether I was doing the right thing and whether it could be applied ...would it be workable...so the lecturer's comments helped" (Student 4: Cohort 2015). This confirms Chawinga's [13] findings that online blog posts ensure that teaching and learning could continue beyond the classroom. As mentioned in this paper, blogs are acceptable means of instructional tools which enable students to construct user-generated sources of information [8]. 


\section{Preparing IL Lessons Using the Framework}

Drafting lesson plans for the various frames also provided students with additional insight into information literacy training and "prepared them with a basis with which to train students" (Student 1: Cohort 2015). Some of them also reported that they were using this method in their workplace: "It [the lesson plans] facilitated my own teaching and practice as a history tutor" (Student 3: Cohort 2017).

Similarly, this type of authentic assessment enables the student to apply the content within a real-world context. Creating a lesson plan for each frame enabled the history tutor to structure his lessons with specific objectives in mind, for instance: "The lesson plans were perfect for history because I wanted students to know that there are various types of authorities that exist and that they are often constructed by your lecturer...they should be able to know which source is more authoritative than the next..." (Student 3: Cohort 2017).

Although a very small percentage of the 15 students in the 2017 cohort are not affiliated with the Library and Information Science discipline and do not work in a library, they have researched the content of each lesson plan very well. (See Fig. 6 in Appendices).

It also became apparent to the researcher that a few lesson plans from the cohorts were replete with grammatical errors and lacked creativity and meticulous planning. This can largely be attributed to the fact that some students do not possess a good command of the English language: "Afrikaans is my first language. The Framework was difficult to understand...the language made is difficult..." (Student 10: Cohort 2015 and 2017). Having repeated and passed the module in 2017, this student feels that the technical language is overwhelming and contributed to his failure in the first year. The researcher intends to revisit the Frames and to customise some of the knowledge practices and dispositions to meet the students' needs and level of understanding. These may be rewritten in a simplified manner to create better comprehension.

\section{(ii) Enhancing Metacognition Through Critical Reflective Practices}

The researcher encouraged students to reflect on the weekly lessons, their experiences, and challenges and to show further readings and research on the respective Frames by providing external links to other sources. The researcher played a significant role in this exercise and provided useful intermediate comments on the blog entries.

As Halbach [10] postulates, the significance of reflection is to assist the student with making the transition between understanding the lecture content and application thereof in debate and discussions. Furthermore, the Framework reinforces the core ideas of metaliteracy which encompass "metacognition or critical self-reflection" [1, p. 3]. This is evident in the following reflection in Fig. 4 where the student relates how he has operationalised the concept Scholarship as a Conversation in his History classes:

\section{(iii) Enhancing Critical Thinking Through Authentic Multimodal Assessments}

The University's Charter of Graduate Attributes refers to multimodal literacy as a competency which is required to use different modes of information to convey meaning. Gunther Kress [19] maintains that "there is an enormous increase in the range 

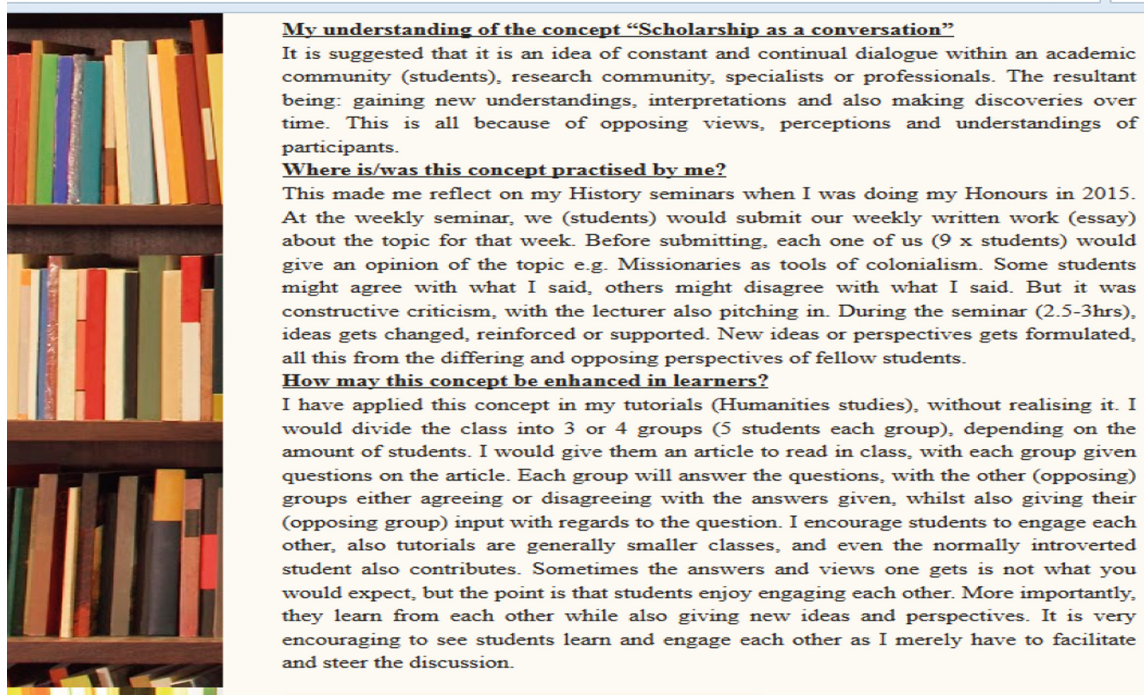

I have applied this concept in my tutorials (Humanities studies), without realising it. I would divide the class into 3 or 4 groups ( 5 students each group), depending on the amount of students. I would give them an article to read in class, with each group given questions on the article. Each group will answer the questions, with the other (opposing) groups either agreeing or disagreeing with the answers given, whilst also giving their (opposing group) input with regards to the question. I encourage students to engage each other, also tutorials are generally smaller classes, and even the normally introverted student also contributes. Sometimes the answers and views one gets is not what you would expect, but the point is that students enjoy engaging each other. More importantly, they learn from each other while also giving new ideas and perspectives. It is very encouraging to see students learn and engage each other as I merely have to facilitate and steer the discussion.

Fig. 4. A reflection by a student in the 2017 cohort

of means for making meaning, as well as in the means for participating in meaningmaking... It is now quite simply impossible to ignore the variety of materials available for making meaning... [19, p. 146]. The development of multimodal literacy is suggested in some of the dispositions of the Framework: Students should "accept that the creation of information may begin initially through communicating in a range of formats or modes" [1, p. 5].

\section{(i) Posters}

Designing a poster provides the student with an opportunity to reflect on the particular processes that are used to create information: “...it was a light and creative manner to bring across one's ideas and thoughts in a medium that was different..." (Student 9: Cohort 2017). "Librarians communicate a lot with patrons using posters or notices...this really helped me with my work as a public librarian" (Student 10: Cohort 2017).

These are some of the criteria which were used to assess the posters: (a) Ideas about the frame should be fully developed and sustained throughout the poster (b) The Frame should be masterfully integrated into the message and poster. Here the researcher also placed emphasis on the use of aesthetics.

The poster in Fig. 5 below illustrates the Frame Research as Inquiry and shows the importance of raising critical questions to shape one's research.

Judging from the few submissions from the 2015 cohort $(n=2)$, it may be inferred that students were, in general, hesitant to express their interpretations through visuals, text and other modes of information: "I didn't understand how to create it electronically, it was going to take too much time" (Student 1: Cohort 2015). More than $60 \%$ of the 2017 cohort elected to design posters. Those who preferred to draft a detailed 


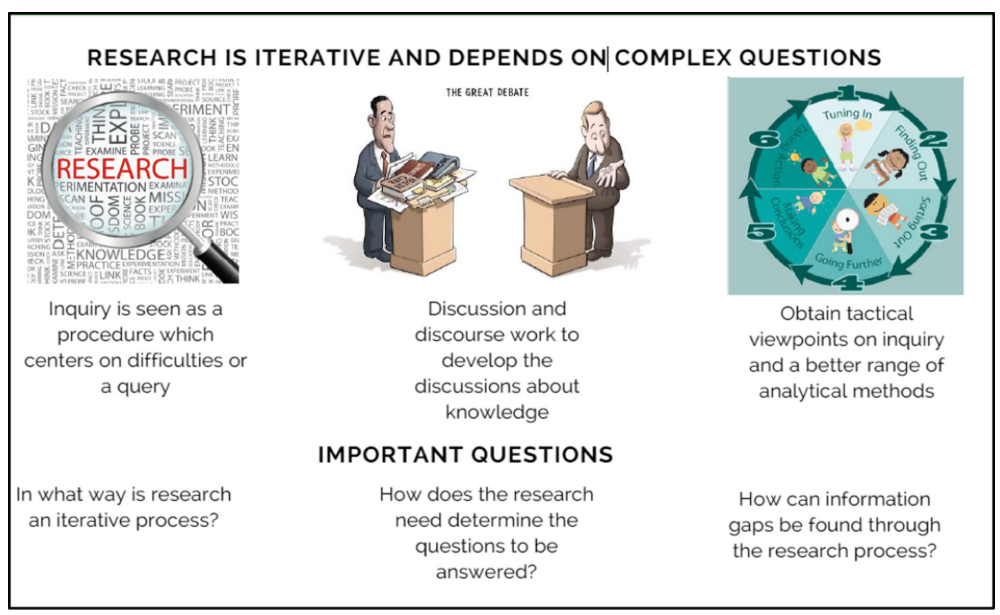

Fig. 5. Poster depicting "Research as Inquiry" (2017 cohort)

teaching scenario attributed their choice to their lack of aesthetic skills: "I did not choose to do a poster because I am not very artistic - I stick to what I do best as a teacher...doing a lesson plan was better for me to explain the Framework" (Student 3: Cohort 2017). Figure 7 illustrates a breakdown of responses to this assessment which includes comments about computer literacy and the impact that the activity had on their understanding of the Frames.

Upon reflection, the researcher believes that a mediated learning approach might be needed with the development of posters. "I prefer that the lecturer shows me how to explain the Frame in a poster ... before I am asked to do it on my own..." (Student 10: Cohort 2015). Despite the fact that she guided her students with creating online posters using a range of software programmes, she considers allowing them to submit drafts of the posters prior to the final due date. In this manner, the student's ability to depict the Framework's elements through multimodality will be sufficiently scaffolded across a series of drafts.

\section{(ii) PowerPoint presentations}

One of the main assignments entailed the planning, structuring and coordination of a workshop for members of the LIS community. The researcher instructed the class to collaborate and to work in teams. The students used PowerPoint slides to prepare their illustrations of how they would organise a workshop in the workplace which is aimed at explaining and analysing the Framework: "I got to learn how to do workshops professionally...now when I run a workshop I know how to plan it properly. "[Student 6, Cohort 2015].

The researcher observed that lively interaction permeated this activity with constructive feedback from the class. She allowed questions from the audience before she posed her critique to the teams. Given the satisfactory performance of the two cohorts in this regard, the majority of the teams delivered acceptable presentations. 


\section{Limitations of the Study}

The researcher managed to interview only $42 \%(n=11)$ of the total number of study subjects $(n=26)$ for both academic years and this may have skewed her results. The data obtained thorough this method provided limited insight into students' experiences with regards to some of the authentic assessments. The restricted number of willing interviewees makes it difficult to conclude whether the assessments have maximised the impact of their critical thinking skills.

\section{Recommendations}

The majority of students claim that the module was saturated with too much content which they were expected to master in a relatively short period of time. It may therefore be suggested that the module should be extended over a year in order for students to gain the maximum benefit from its learning objectives. Moreover, the Framework is aimed at academic librarians whose core function is to teach students and researchers how to navigate the nuances of the $21^{\text {st }}$ Century information landscape. Those who serve in community libraries struggle to plan hypothetical training sessions as they have not been exposed to IL training of this nature: "The Framework is for mostly for Higher Education... and to ask librarians who work at public or special libraries to use it will confuse them....they might not be allowed to implement the frames in their work as it [the Framework] is meant for higher education" (Student 2:2017) To alleviate this concern, the researcher recommends that her praxis includes demonstrating ways in which the Framework could be used by public librarians in their IL training of Primary and Secondary school learners.

\section{Conclusion}

It may be inferred that the Framework's constructivist and inquiry-based learning principles are favourable for fostering autonomous and critical thought. The ACRL Framework provides a nuanced approach to information literacy which enables librarians to evaluate critical thinking through authentic and other assessment types. This study confirms that the Framework presents a new way in which information literacy may be viewed and assessed. It proves that by using formative and summative evaluation techniques, librarians would be able to measure higher order thinking skills and determine the impact that their IL training has on students. More importantly, the study described how the ACRL Framework could be embedded in the ILE module and how it could be operationalised so that prospective librarians are able to internalise the threshold concepts.

Acknowledgements. The author would like to thank the graduates of the LBS707 course for the years 2015 and 2017 who have unwaveringly granted her their permission to utilise their artifacts for this paper. 


\section{Appendix}

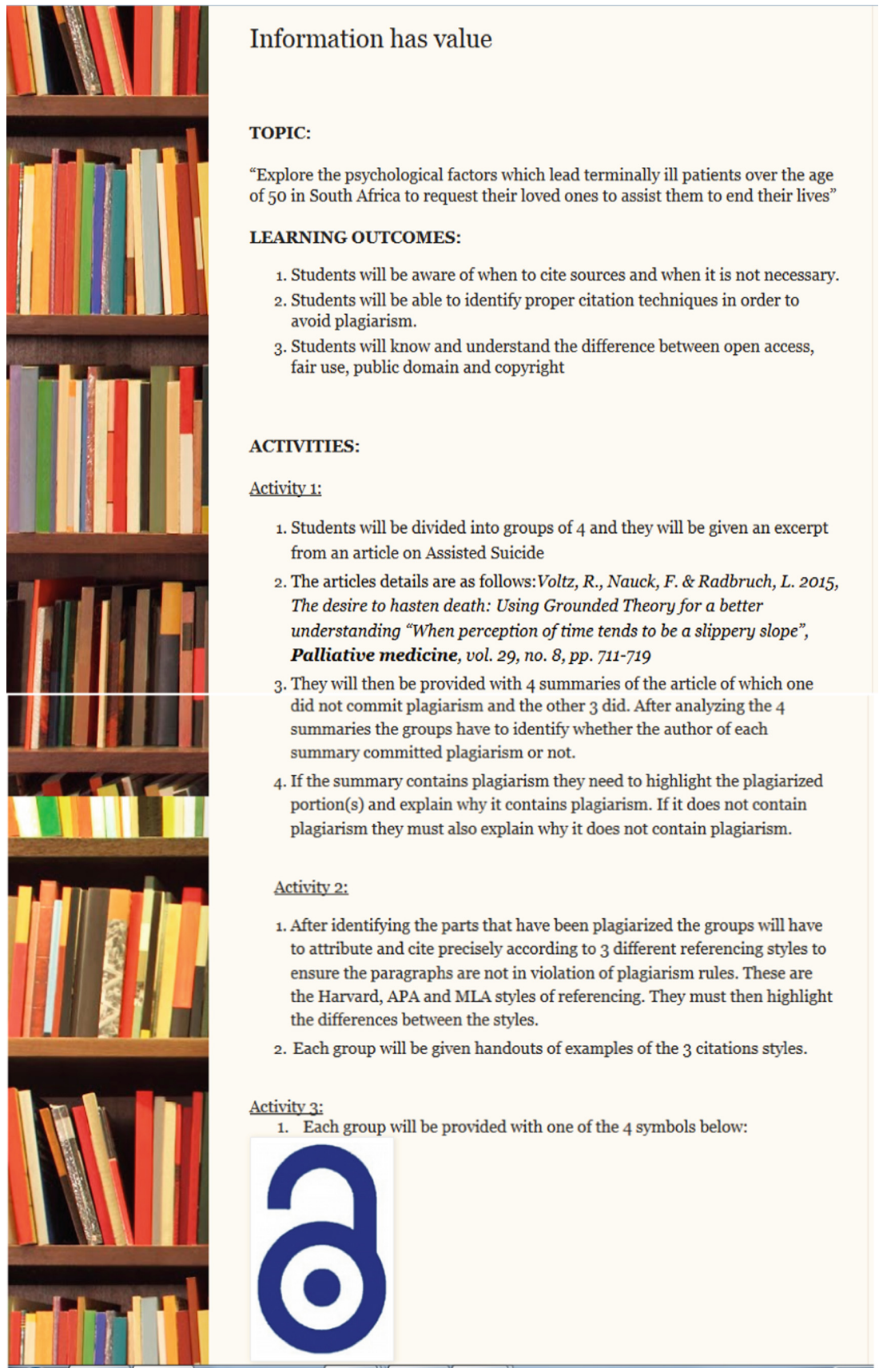

Fig. 6. A lesson plan depicting the frame "Information has Value" 


\section{Has designing a poster assisted you with understanding the Frames? Motivate.}

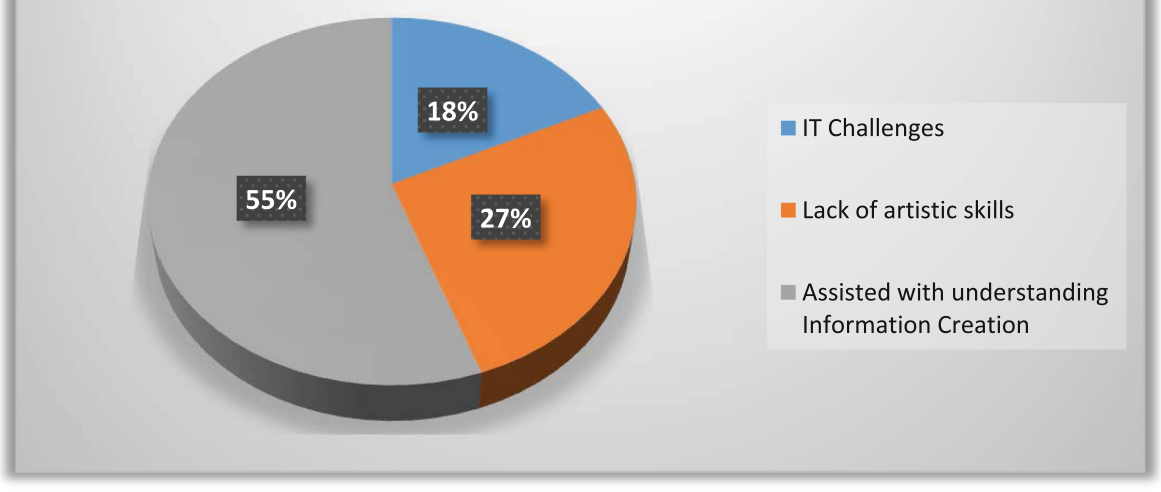

Fig. 7. Student feedback on poster assessment

\section{References}

1. Association of College \& Research Libraries: Framework for Information Literacy For Higher Education (2016)

2. Association of College \& Research Libraries: Information Literacy Competency Standards for Higher Education (2000)

3. Hepworth, M.: Teaching Information Literacy for Inquiry-Based Learning. Chandos Publishing, Oxford (2009)

4. Elmborg, J.: Critical information literacy: implications for instructional practice. J. Acad. Librarianship 32(2), 192-199 (2006). https://doi.org/10.1016/j.acalib.2005.12.004

5. Fullard, A.: Using the ACRL framework for information literacy to foster teaching and learning partnerships. SUN (2017)

6. Freire, P., Ramos, M.B.: Pedagogy of the Oppressed. Penguin, Harmondsworth (1972)

7. Bauder, J., Rod, C.: Crossing thresholds: critical information literacy pedagogy and the ACRL framework. Coll. Undergraduate Libr. 23(3), 252-264 (2016)

8. Anderson, M.: Rethinking Assessment: Information Literacy Instruction and the ACRL Framework. SLIS Student Res. J. 5(2), 1-10 (2015)

9. Whitlock, B., Nanavati, J.: A systematic approach to performative and authentic assessment. Ref. Serv. Rev. 41(1), 32-48 (2013)

10. Halbach, A.: Exporting methodologies: the reflective approach in teacher training. Lang. Cult. Curriculum 15(3), 243-450 (2002)

11. Couture, J., Ladenson, S.: Research as inquiry in women's and gender studies. In: Godbey, S., Wainscott, S., Goodman, X. (eds.) Association of College and Research Libraries, Disciplinary Applications of Information Literacy Threshold Concepts (2017) 
12. Brookfield, S., Preskill, S.: Discussion as a Way of Teaching: Tools and Techniques for Democratic Classrooms, 2nd edn. Jossey-Bass, San Francisco (2005)

13. Chawinga, W.: Taking social media to a university classroom: teaching and learning using Twitter and blogs. Int. J. Educ. Technol. High. Educ. 14(1), 1-19 (2017)

14. Yin, R.: Applications of Case Study Research, 2nd edn. Sage Publications, Thousand Oaks (2003)

15. Gorman, G.E., et al.: Qualitative Research for the Information Professional: a Practical Handbook. Library Association Publishing, London (1997)

16. Ferreira, S.: Critical Moments Reflection Methodology (2008). http://web.mit.edu/cil/web.../ Critical\%20Moments\%20Methodology\%20Brief\%20CoLab.pd

17. Fook, J.: Developing critical reflection as a research method. In: Higgs, J., et al., (eds.) Creative Spaces for Qualitative Researching: Living Research, pp. 65-76. Sense Publishers (2011)

18. Haigh, J.: Teaching the teachers: the value of information for educators. In: Godbey, S., Wainscott, S., Goodman, X. (eds.) Association of College and Research Libraries, Disciplinary Applications of Information Literacy Threshold Concepts (2017)

19. Kress, G.: Design: the rhetorical work of shaping the semiotic world 2014. In: Archer, A., Newfield, D. (eds.) Multimodal Approaches to Research and Pedagogy: Recognition, Resources, and Access. Routledge, New York (2014) 